\title{
New Approach of Managerial Modules Framework in Human Resources Excellence Model
}

\author{
Behdad Mirafshar $^{1}$, Hassan Danadeh ${ }^{2}$, Mehrdad Solgi $^{3}$ \\ ${ }^{1}$ Department of Information and Technology of Management, Electronic Branch, Islamic Azad University, Tehran, Iran \\ ${ }^{2}$ Department of Urban and Land Use Planning, North Tehran Branch, Islamic Azad University, Tehran, Iran \\ ${ }^{3}$ Department of Management and Economics, Science and Research Branch, Islamic Azad University, Tehran, Iran
}

\section{Email address:}

Bezad.af@gmail.com (B. Mirafshar), danandehhassan1234@gmail.com (H. Danandeh), Mehrdad_solgi@yahoo.com (M. Solgi)

\section{To cite this article:}

Behdad Mirafshar, Hassan Danadeh, Mehrdad Solgi. New Approach of Managerial Modules Framework in Human Resources Excellence Model. Education Journal. Special Issue: Learning Management System, Human Resources Excellence Model, Smart Urban Governance, Social Organization Intelligence. Vol. 8, No. 6, 2019, pp. 274-278. doi: 10.11648/j.edu.20190806.16

Received: September 17, 2019; Accepted: October 15, 2019; Published: November 5, 2019

\begin{abstract}
The purpose of this study is related to the some questions raised during the establishment of the human resource Excellency model 17 in Tehran Municipality. To illustrate how other organizational management issues appropriate into this model. Which leads to the abstract drawing of 37 management modules within the Human Resource (HR) model, extracted from the experiential background of consulting and training of organizations and companies implementing human resource excellence model to get a more comprehensive, engaging look at the issues involved in science management And be able to visualize a set of modules, systems, processes, and management issues needed by organizations within the model which, in addition to outlining the strategic plan of the deployment, has led to their maturing over period of time And determine how to deliver organizational quality services and products to society. Hence at the beginning of this research in the framework of the Excellency model, 37 management modules in an organization that can be used with different ways based on the experiences of implementation in the 17th district municipality of Tehran, The researcher carefully arranged each of them into the criteria of the model to develop a researcher mind made framework. Then, validated statistical tests such as factor analysis, multiple regression and correlation test were used to evaluate the model. Finally, the validity of this abstract management framework was confirmed after analyzing the data in Table 2. In order to prove the hypothesis that besides the HR model, an innovative framework of management systems and processes for the organization can be illustrated in the strategic road map.
\end{abstract}

Keywords: Human Resources Excellence Model, Managerial Modules Framework, Life Cycle of Excellence, Comprehensive Approach, Strategic Road Map

\section{Introduction}

Human resources excellence is mentioned in numerous books and articles that by utilizing tools and technologies, organizational resources, effective leadership, and other factors, it can perform a variety of functions. Including these functions can be used to evaluate employee performance, the effectiveness of human resources (perspective of strategic management) or quality management and workforce productivity $[1,2]$. On the other hand, productive international competition is emerging among the leading organizations and companies in the national award for excellence or excellence every year. In witch, constructive international competition is emerging among the leading organizations and companies in the National Award of Excellency every year. So the best in the field of manufacturing and services from the perspective of this model are known among companies [3, 4].

On the other hand, some companies are proud of having accredited scientific associations to keep their honors in the collection. In management science, every managerial model for survival in an organization has a life cycle when the model is taught, it is deployed and then developed until to lose their effectiveness and disappear over time [5]. However, the main question before this research is how to present this model in a new format of scientific framework in order to make it more effectiveness and efficiency for its 
stakeholders than ever before. So the question this research can be paraphrased as: Is it possible to human resource excellence model consist of 9 criteria and 30 sub-criteria with Radar Logic analysis imagine other special framework to show a new view of potential?

In March 2019, the World Association of Excellence has designed a special program for model assessors of excellence in its annual training calendar with the keyword Innovation Excellence. Its purpose is summarized in 4 sections: Routing Innovation, Creating Innovation, Calibrating and Measuring Innovation Results in Organizations and Employees, Products and Services. In fact that to present innovative ideas of employees and output products sector, innovation excellence model is required $[6,7]$.

While training, consulting, deploying and evaluating the HRM model, fundamental questions about this model are posed by experts, practitioners and practitioners of this model. For example, what is the relationship between different standards with this model? Is quality management a part of this Model?

It is even observed that some executives confuse all types of standards with this framework and consider it only a national award certificate. However, the scientific and empirical background of the two decades of model deployment and development in Iran disagree these assumptions. Since this model has a logic and principles framework, some core modules of management sciences and techniques can be added to this framework. So that, each can have a unique place in this model $[8,9]$.

Conducted by the Human Resources Management Association of Iran in the empirical research conducted during the consultation and deployment in Tehran municipality (region17) after the deployment and selfassessment, realized that by drawing on the framework of this model in the form of 37 management modules, it would be possible to provide a more comprehensive answer to the numerous questions of excellence enthusiasts. The template 37 management modules in the HRM model are thematic for further academic research at postgraduate and doctoral level students interested in management science to use research results to better understand and develop the model [10-12].

In this respect, it is another advantage to include comprehensive models for leading organizations and companies in the field to continue their work in excellence with greater confidence and motivation so be able to deploy and deploy the required management modules in their comprehensive strategic plan be defining operational plans. This research was attempted by studying the new version of Enterprise Excellence Model 2015 version (E. F. Q. M) categorizes information resources, types of new skills and tools in management, humanities and engineering sciences to managerial modules framework is illustrated in accordance with the Excellence Model. For example, when it comes to leadership criteria, there are issues such as coaching, effective communication management, change management, and teamwork or, in the strategic criteria, the second part of the model: forecasting, Linear or Nonlinear Strategic Planning are illustrated as modules. As for the Process Criteria, which relate to Criteria 3, 4, 5, 6 Human Resource Excellence Model, issues such as standardization, security, quality, engineering, risk and processes alignment are addressed along with the results of their actions within the management modules [13, 14].

It can be presented and mapped within the model as shown below Subjects gathered from other sciences and techniques have the potential to be semantic in this context to bring together a different and comprehensive view of the synergy of management science topics. The following table is a set of templates, methods, tools to choose the best for an organization in excellency road map that is going to move forward, continuously, effectively and long-term [15].

Table 1. Managerial modules framework (made by researcher).

\begin{tabular}{|c|c|c|}
\hline Leadership Criteria & Processes \& Systems management Criteria & Perceptual results Criteria \\
\hline 1. Coaching \& Mentoring & 1. Integrated service management systems & 1. Customer relationship management \\
\hline 2. Systematic Inclusive Approach & 2. Enterprise Resource Planning & 2. Engagement Survey \\
\hline 3. Effective communication skills & 3. Enterprise Systems Management & 3. Organizational Culture \\
\hline 4. Team working skill & 4. Information security management system & 4. Knowledge management \\
\hline 5. Knowledge of problem solving techniques & 5. Information Technology Infrastructure Library & 5. Organizational behaviour \\
\hline 6. Method of Creating Idea & 6. Total Quality management & Functional results of processes Criteria \\
\hline 7. Change management & 7. Managing Standards Deployment & 1. Key Performance Indicator \\
\hline 1. Strategic planning & 9. Risk analysis of Activities & 3. Documenting successful experiences \\
\hline 2. Operational Planning & 10. Health, safety, environment & 4. Performance Improvement Management \\
\hline \multirow[t]{4}{*}{ 3. Forecasting } & & 5. Documentation Management \\
\hline & & Organization results Criteria \\
\hline & & 1. Evaluating the effectiveness of strategies \\
\hline & & $\begin{array}{l}\text { 2. Organizational Dashboard measuring key } \\
\text { indicators }\end{array}$ \\
\hline
\end{tabular}

\section{Materials and Methods}

The purpose of this study was to determine the relationship between the 37 managerial modules related to the main criteria of the Excellence Model, so together they form the model structure and provide a new framework for the arrangement of management components in the HRM model. This research is an applied and descriptive-survey method. In this method, partial least squares technique is used to 
estimate the model and its component parts [16].

A partial least squares method based on regression modeling is analyzed by software of the same name (smart partial squares software). The proposed method determines the coefficients so that the resulting model has the most power of interpretation and explanation; that is, the model can predict the final dependent variable with the highest accuracy. [10]

This method is suitable for measuring the overall impact of structures on each other, In addition in order to find out the underlying components of human resource excellence model and to evaluate model construct validity by software, confirmatory factor analysis and multiple regression techniques are used [17].

The statistical population of this research is 700 men and women of the staff and managers of the queues and headquarters of the Tehran Municipality region 17. For the sampling and estimation of sample size the Krejcie and Morgan method and related tables (in cases where there is no society variance or percentage error and the size of society is known) were used. 291 employees and managers of the headquarters and 22 districts of Tehran Municipality in the field of human resource development, were selected randomly.

\section{Results and Discussion}

In order to perform the structural validity of the research model, the Fornell and Larcker [18], techniques were used in partial least squares method and the software was based on the average of the extracted variance, which calculated the average value of the factors (Thirty-seven variables) of 5.192, which is due to being larger than the validity index (0.5) can be considered as the reliability of the structure's validity. Also, according to the results of the table below the Sig statistic that is less than 0.01 (error rate 10\%), the assumption of linearity of the model and its components is confirmed [19].

Table 2. Results of Factor Analysis of Model Components.

\begin{tabular}{|c|c|c|c|c|}
\hline Criterion factors & Components corresponding to each criterion & Factor loads & Sig statistic & R2 statistic \\
\hline \multirow{6}{*}{ Leadership Criterion } & Coaching, Mentoring & 0.742 & $<0.01$ & 0.674 \\
\hline & Systematic attitude & 0.79 & $<0.01$ & 0.572 \\
\hline & Effective communication skills & 0.65 & $<0.01$ & 0.544 \\
\hline & Team working skills & 0.436 & $<0.01$ & 0.539 \\
\hline & Knowledge of problem solving techniques & 0.625 & $<0.01$ & 0.537 \\
\hline & Creating ideas method & 0.764 & $<0.01$ & 0.547 \\
\hline \multirow{2}{*}{ Strategy criterion } & Change management & 0.729 & $<0.01$ & 0.568 \\
\hline & linear programming & 0.687 & $<0.01$ & 0.578 \\
\hline \multirow{10}{*}{ Processes criterion } & Forecasting & 0.803 & $<0.01$ & 0.664 \\
\hline & Processing control management & 0.754 & $<0.01$ & 0.679 \\
\hline & System design engineering & 0.532 & $<0.01$ & 0.653 \\
\hline & Integrated Services Management & 0.674 & $<0.01$ & 0.661 \\
\hline & Enterprise Resource Planning & 0.576 & $<0.01$ & 0.617 \\
\hline & Enterprise Systems Management & 0.598 & $<0.01$ & 0.636 \\
\hline & Total quality management & 0.741 & $<0.01$ & 0.672 \\
\hline & Managing Standards Deployment & 0.637 & $<0.01$ & 0.667 \\
\hline & Project control management & 0.672 & $<0.01$ & 0.665 \\
\hline & Risk analysis & 0.545 & $<0.01$ & 0.599 \\
\hline \multirow{6}{*}{$\begin{array}{l}\text { Perceptual results } \\
\text { criterion }\end{array}$} & Health. Safety. Environment & 0.811 & $<0.01$ & 0.704 \\
\hline & Customer relationship management & 0.525 & $<0.01$ & 0.583 \\
\hline & Organizational Commitment & 0.776 & $<0.01$ & 0.649 \\
\hline & Organizational Culture & 0.807 & $<0.01$ & 0.661 \\
\hline & Knowledge management & 0.794 & $<0.01$ & 0.628 \\
\hline & Organizational behaviour & 0.662 & $<0.01$ & 0.609 \\
\hline \multirow{4}{*}{$\begin{array}{l}\text { Functional results } \\
\text { criterion }\end{array}$} & Key performance Indicators & 0.726 & $<0.01$ & 0.673 \\
\hline & Performance Report designing & 0.781 & $<0.01$ & 0.691 \\
\hline & Documenting successful experiences & 0.835 & $<0.01$ & 0.679 \\
\hline & Improvement management & 0.761 & $<0.01$ & 0.68 \\
\hline $\begin{array}{l}\text { Organization results } \\
\text { criterion }\end{array}$ & Documentation Management & 0.832 & $<0.01$ & 0.578 \\
\hline
\end{tabular}

In order to discover the constituent factors of each construct, a confirmed factor analysis was used. The value of correlation test $\left(\mathrm{R}^{2}\right.$ statistic) in the table above shows the correlation of variables in the model structure. Because the value of this statistic for each variable is greater than 0.5 . Regarding the analytical results of the confirmatory factor it can be mentioned that to determine which index has a significant contribution to measuring the research structures and which index does not. The factor load for each measure should be more than 0.4 , otherwise it should be tested again.

In this context, comparing the loads of each of the components of the model criteria with this value shows a 
greater and more significant contribution to each other.

For example, the component of forecasting plays a greater role in the strategy criteria of Excellency model. In addition, the GOF index is also an indicator for examining fit of the model to predict endogenous variables. The three values of $0.25,0.36$ and 0.01 , have been presented as weak, moderate and strong values for the model fitness respectively. Based on formula and the numbers obtained from Table 2:

$$
\mathrm{GOF}=\sqrt{\text { communalities } * r^{2}}
$$

The result of the fitting index is 0.559 , which is greater than 0.36 and shows an appropriate fit for the research model, as well as all path coefficients are significant, and the explained variance is acceptable and the internal consistency of the structures is higher than 0.04 .

\section{Conclusion}

Some organizations are keen on knowledge management, others on standards, change management, teamwork or coaching in period of the time. However, in the theoretical literature, complete enterprise has a comprehensive look at their needs and stakeholders. Another benefit of having a guest is a comprehensive look at systems and processes.

For example, in the municipality of Tehran, along with four main processes of human resource development (planning and provision, compensation of services and human resource development along with labor and staff relations), other job occupations are seen such as urban services, civil and transport and traffic, cultural and social, architecture, urban planning, finance and planning. In addition, they play a key role in creating key organizational outcomes [20].

Although this is the case in other manufacturing and service companies, drawing such a model would be beneficial. In addition to the criteria and sub-criteria it can display a variety of management modules to make the management system map for an organization more clearly and also to describe more precisely the meaning of systems and processes integrated within the organization [21].

Since it is proven that having only one or more systems and processes alone is not enough for an organization, such a model can be put forward to senior managers to draw a vision of the future leading organization. So that they can select and optimize the best systems and processes based on their missions from the module portfolio. In addition, one can expect the step of evaluating this framework by trained evaluators to seek applicants for the National Excellence Award in addition to evaluating the criteria for such modules in the organization, to enrich the quality results. Drawing these modules in the model of Excellency also assures leaders and experts of systems.

In addition to benefiting from systems and processes defined in current tasks, they sense the meanings of subjects such as knowledge creation, continuous improvement, process refinement at work well than ever before, and more deeply motivated work.

Along with this creative imagination that the lifecycle of the model of excellence lasts for many years and that organizations accept it. That way quality should be systematically institutionalized in the set of units

Organizations usually want to be the leader among competitors and competitors. Although performance results show trends, but solutions can also be suggested In other words, in addition to offering points of improvement, one or more management modules can be offered to each organization in order to improve the criteria.

Finally, portraying the model in this way can lead to greater attraction for stakeholders and the high capacity to adopt other sciences and techniques in the organization. It lists a variety of application management modules in the list of future plans for organizations and companies. Also, the table1 described in terms of relationship between variables and structural validity is in line with the analytical findings of the study, which divided the model of excellence (with 6 criterion) into 37 managerial modules and its accuracy was confirmed by the above tests.

\section{References}

[1] Gene - Badia, j, et al, 2010, "the EFQM excellence model is useful for primary health care teams", an international Journal of family practice, Vol 18, No4, pp: 407-40.

[2] M. Najmi, S. Hoseini, 2004, "EFQM Excellence Model from Idea to Action "Tehran, Saramad publication, vol. 7.

[3] Michalska, j, 2008, "using the EFQM excellence model to the process assessment", Journal of Achievements and manufacturing Engineering" vol 27. Issue2, pp: 203-206.

[4] A. Khorasani, et al, 2014, "Iran Human Resource Development and Excellence Model". Tehran, Iranian Center for Industrial Research and Training, vol. 6.

[5] Sanchez, Elena, et al, 2006, "A descriptive study of the implementation of the EFQM excellence model and underlying tools in the Basque health service", international journal for quality in health care, Volume 18, number1. pp: 58-65.

[6] Longbottom, D. (2008). The need for education and training in the use of the organizational excellence models for quality management in UK higher education institutions. Quality Assurance in education. 10 (1): 26-36.

[7] R. Tavakoli, B. Beheshtipour, 2012, "Principles of organizational excellency". Tehran, Resa publication, vol. 2.

[8] J. Heir, T. Halt, C. Rincle, 2015, “A primer on partial least squares structural equation modeling (pls-sem)" Tehran, Look at knowledge publication, vol. 1, Translated by Adel Azar and Rasool Gholamzadeh.

[9] H. Amiran, 2010, “A Step-by-Step Guide to Organization Excellence by E. F. Q. M Model”. Tehran, vol. 3.

[10] Calvo-Mora. A, et al. (2018). Assessment and improvement of organisational social impact through the EFQM Excellence Model. Journal of Total Quality Management \& Business Excellence. Volume 29, 2018 - Issue 11-12. 
[11] K. Fathi vageragah, M. Fariborz, 2016, "Fundamentals of Quality Management in Training and Improvement of Human Resources "Tehran, Resa publication Aige, vol. 7.

[12] Tee Ng, Pak and Chan, D. (2008). A comparative study of Sigapores school excellence model with Hong Kongs School Based management. International Journal of Education research. 22 (6): 22-65.

[13] Vallejo, Paula, et al, 2007, "improving quality of the hospital psychiatric ward level through the use of the EFQM model", International journal for quality in health care, Volume 19, Number2, pp: 74-79.

[14] Joshaghani, M. saghaei, A. Setak, M. (2018). The causal structure of the excellence model for work units. Journal of Total Quality Management \& Business Excellence. Published online: 13 Aug 2019.

[15] Kolus, A. Wells, R. Neumann, P. (2018). Production quality and human factors engineering: A systematic review and theoretical framework. Journal of Applied Ergonomics. Volume 73, November 2018, Pages 55-89.

[16] Bastas, A. Liyange, K.(2018). Sustainable supply chain quality management: A systematic review. Journal of Cleaner Production. Volume 181, 20 April 2018, Pages 726-744.
[17] Deshpande, A. (2019). Total Quality Management, Concurrent Engineering and Manufacturing Performance: An Empirical Investigation. Journal of Operations and Strategic Planning. First Published June 7, 2019.

[18] Fornell, C. Larcker, D. Evaluating structural equation models with unobservable variables and measurement error. Journal of marketing research. First Published date 1981, pages 39-50.

[19] Nicker, S. Singh, A. (2019). Developing a framework towards improving business analysis of integrated public e-service systems. IEEE Xplore digital library. Published in: 2019 Conference on Information Communications Technology and Society (ICTAS), Durban, South Africa, South Africa.

[20] Khalili, A. et all. (2017). Integration of lean manufacturing and quality management system through structural equation modelling. Published online 16 March 2017. Published in Inderscience Journal online.

[21] S. Nallusamy. (2016). A Proposed Model for Sustaining Quality Assurance Using TQM Practices in Small and Medium Scale Industries. International Journal of Engineering Research in Africa Vol. 22. 184-190. 